EPiC Series in Biological Sciences
Volume 1, 2021, Pages 112-117
$\begin{gathered}\text { Proceedings of KOBI 2nd International Confer- } \\ \text { ence on Management of Tropical Biodiversity for } \\ \text { Human Welfare: From Ecosystem to Molecular }\end{gathered}$

\title{
Reading, Mind Mapping, Sharing (RMS) on The Material of Human Reproductive System: Its Effectivity to Students' Higher Order Thinking Skill (HOTS)
}

\author{
Banita Eka Putri ${ }^{1 *}$, Arif Didik Kurniawan ${ }^{1}$, Ari Sunandar ${ }^{1}$ \\ ${ }^{1}$ Universitas Muhammadiyah Pontianak, Pontianak, Indonesia \\ nitabanitegmail.com
}

\begin{abstract}
In the $21^{\text {st }}$ century, there are some competencies that all students must have such as critical and creative thinking, and innovation which is included in Higher Order Thinking Skills (HOTS). However, the accomplishment of HOTS in Indonesia is still considered low, and reading, mind mapping, sharing (RMS) hasn't been used in improving HOTS. In the RMS model, the students learn to make a mind map that helps them to think and become creative in one activity. Therefore, it is necessary to research about students' HOTS with RMS learning model. This study aimed to see the effectivity of the RMS learning model on students' HOTS in biology. The method used in this research was quasi-experimental with a non-equivalent group design. The sampling technique used in SMAN 1 Ambawang of Kubu Raya Regency was a purposive sampling technique with class XI MIPA 3 as experimental class and class XI MIPA 4 as a control class. The study showed that the RMS learning model was effective (effect size $=0.6$ or categorized in medium level) and could give an impact on students' HOTS in learning the material of the human reproductive system. The result of average Gain value to test the impact of RMS towards students' HOTS for class XI MIPA 3 was 45.51 and for class XI MIPA 4 was 38.10. The effectivity of RMS was tested with effect size test and the result showed is 0.6 , characterized as medium level.
\end{abstract}

\section{Introduction}

IT has become the basis in human life in the era of industrial revolution 4.0. (Kemristekdikti, 2018). The progress of the quality of civilization has no longer relied on the strength of natural resources but is greatly influenced by the quality of human resources. Qualified human resources are expected to increase the living standards and prosperity of nations, also can increase sustainable 
development. Therefore, a qualified education is necessary to produce graduates who are expected to be qualified human resources (Dewi, 2016). The quality of education in Indonesia is still low, still far from the desired expectation. Following Jalal (2009), on the international level, the quality of education in Indonesia is still far from expectations. This condition can be seen from the achievement of Indonesian students at TIMSS (Trend International Mathematics and Science Study) (Balitbang, 2011) which continues to decline from year to year. In 2011, Indonesia was ranked 40 out of 42 , meanwhile, the achievement of natural science literacy at PISA (Programme for International Student Assessment) in 2012, Indonesia was ranked 64 out of 65 countries (OECD, 2014).

Based on the $21^{\text {st }}$-century ideal learning, there are some competencies that all students must have including critical thinking skills, collaboration skills, innovative skills, creative thinking skills, IT skills, and communication skills (Supriatna, 2018). Creative and critical thinking skills are included in a skill called higher-order thinking skills (HOTS) which covers the skills of analyzing, evaluating, and creating (Prasetyani, 2016). Individuals who have a high level of critical thinking will be able to formulate problems, gather and assess relevant information, use abstract ideas, and open-minded. Someone who is used to critical thinking tends to seek the truth, able to analyze problems well, think systematically, curious, and become mature in thinking (Ramadhan, 2016). HOTS helps students to develop their skills in making decisions, evaluating, and solving problems appropriately (Hidayat, 2012). It is expected that students in the era of industrial revolution 4.0, can adjust to the condition and the dynamics. Therefore, HOTS is one of the important aspects to cope with the needs of industrial revolution 4.0 which can be equipped with training.

According to Fayakun \& Purnomo (2015), HOTS covers cognitive skills in analyzing (C4), evaluating (C5), and creating (C6). Teachers should lead the learning process to where students can practice their HOTS. The previous learning method should be modified to improve students' HOTS by applying an appropriate model. One of the models which can help improve students' HOTS is RMS (reading, mind mapping, sharing). According to Diani (2018), RMS learning model brings a good influence on students' HOTS because, in RMS learning model, the implementation of learning is adjusted to the concept of constructivism learning where studying is not merely about absorbing information, ideas, and abilities but also building and improving by the doer (Muhlisin, 2016).

Several studies on higher-order thinking skills have been carried out. Raudenbush (1992) concluded that the teacher's good understanding of HOTS could give a significant impact on teachers' preparation in teaching HOTS to their students. Moreover, Lewy (2009) suggested using questions at HOTS level. However, students might face some obstacles in solving HOTS level questions due to the lack of student's persistence and student's inattention in thinking (Prasetyani, 2016).

RMS is a learning model that requires students to practice their HOTS by making a mind map. In Anderson's taxonomy, making a mind map is included in the C6 indicator (creating). The social aspect of RMS refers to development theory from Vygotsky where individuals help each other develop individual knowledge. Social interaction with others can lead to new ideas and improve individual knowledge (Diani, 2018). The steps in implementing RMS are reading literature or book about the material, making a mind map, and sharing what they have made in the mind map in front of the class (Muhlisin, 2016).

\section{Method}

This study used a quasi-experimental method with a non-equivalent group design. Pretest and posttest were performed in both control and experimental groups. This study used 31 students in each class. The pretest was given to both classes before the students received the learning process and the posttest was given after the learning process.

RMS learning model application was done by dividing the students into 6 groups of 5 people per 
group. Before starting the lessons, the students were given a pretest. This pretest serves to determine the initial knowledge of learners in the subject matter learned that the reproductive system. Furthermore, students were asked to read LKPD (worksheet) given by the teacher for 15 minutes. This reading activity aimed to enable students to get information about the reproductive system materials before making a mind map. Mind maps created by students can help students to develop their creativity in making a mind map because students are required to create as much freedom as possible to map out their thoughts. At the end of the study, students were asked to present the results of their discussion that has been manifested in a mind map.

The control class used concept mapping for the treatment. The stages of concept mapping are similar to RMS but the final product the students make is a concept map. The aim of using concept mapping was to find which learning model will be more suitable to increase students' HOTS since both learning models have similar stages of the learning process.

Data analysis in this study used IBM SPSS 21.0 to test the normality of the data with KolmogorovSmirnov and to test the hypothesis with U-Mann Whitney. The effectivity of the RMS learning model was tested with effect size test, which aims to determine the impact of the RMS learning model on students' HOTS. The effect size can be measured with an equation that has been described in more detail by Cohen (1988) as followed:

$$
\mathrm{d}=(\mathrm{mA}-\mathrm{mB}) /[(\mathrm{sd} 2 \mathrm{~A}+\mathrm{sdB} 2) / 2] 1 / 2
$$

where $d$ is the effect size, $m_{A}$ is the average gain value of experiment class, $m_{B}$ is the average gain value of control class, $\mathrm{sd}_{\mathrm{A}}$ is the standard deviation of experiment class, and $\mathrm{sd}_{\mathrm{B}}$ is the standard deviation of the control class. The value of the effect then categorized into three under Saregar (2016) as shown in the table below:

\begin{tabular}{cc}
\hline Effect Size & Criteria \\
\hline $\mathrm{d}<0.2$ & Small \\
\hline $0.2<\mathrm{d}<0.8$ & Medium \\
\hline $\mathrm{d}>0.8$ & High \\
\hline
\end{tabular}

Table 1: Criteria of Effect Size according to Saregar (2016)

\section{Results and Discussion}

Data of students' HOTS were obtained from pretest and posttest results using HOTS questions which measured at the beginning and the end of the study. The test consisted of 5 essay questions with 3 indicators of HOTS (analyzing, evaluating, and creating) to measure students' HOTS for both control class and experimental class.

\begin{tabular}{|c|c|c|c|c|c|c|}
\hline \multirow[b]{2}{*}{ Class } & \multicolumn{2}{|c|}{ Average Score } & \multirow[b]{2}{*}{ N-Gain } & \multirow{2}{*}{$\begin{array}{l}\text { Standard } \\
\text { Deviation }\end{array}$} & \multirow[b]{2}{*}{ Effect Size } & \multirow[b]{2}{*}{ Category } \\
\hline & Pretest & Posttest & & & & \\
\hline $\begin{array}{l}\text { Experimental } \\
\text { Group }\end{array}$ & 9.31 & 54.82 & 45.51 & 11.28 & 0.60 & Medium \\
\hline Control Group & 10 & 48.10 & 38.10 & 12.98 & & \\
\hline
\end{tabular}

Table 2: Average Value of HOTS Score and Effect Size Value Description: $\mathrm{N}-$ Gain $=$ posttest value - pretest value 
There is an increase in the value of the posttest in the experimental class and control class compared to the pretest value. Based on the value of the gain, HOTS in class that used the RMS model was higher than the class that used concept mapping with the difference in the gain value of 7.41. The effect size of 0.60, classified in the medium category (Saregar, 2016). RMS learning model application on the material of the human reproductive system showed that the model could improve the HOTS among students at SMAN 1 Ambawang. There is a slight difference between the experimental class and control class, but the U-Mann Whitney test confirmed that the difference was not significant (Table 3).

\begin{tabular}{|l|c|}
\hline & Value \\
\hline Mann-Whitney U & 284.000 \\
Wilcoxon W & 719.000 \\
Z & -2.142 \\
Asymp. Sig. (2-tailed) &, 032 \\
\hline
\end{tabular}

Table 3: Result of U-Mann Whitney Test

Model concept mapping which applied in the control class had the same steps, only the final products were different. In the RMS learning model, the product they made was mind map, but in concept mapping model the product they made was a concept map. Although the concept map and mind map look similar, the two things have turned out differently. Concept maps and mind maps are different in the structure of the writing. Concept maps have a clear hierarchy or levels, are also used to connect a single concept with other concepts. Besides, the concept map is also usually more formal and a bit stiff. Otherwise, mind maps are more flexible, more spontaneous, and can be made based on creativity (Eppler, 2006). Characteristics of concept maps that seemed stiff and monotonous became one of the factors why the Gain value in the experimental class was higher.

At first, there was difficulty in researching SMA Negeri 1 Ambawang because the learning process that led to students' improvement on HOTS had never been implemented. The interview result with the biology teachers confirmed that students had never been given HOTS level questions. This circumstance made the student unfamiliar with HOTS level questions. It can be seen from the pretest result from both classes with the average value of 9,31 for experiment class and 10 for control class. After the treatments were given, the result of the posttest from both classes increased with the average value of 54,82 for experiment class and 48,10 for the control class.

Even though the result of the test still hasn't passed the school's minimum score of 78, there was an improvement in their HOTS scores. The scores improvement suggested that the students' understanding was developed through every step of the RMS learning model. Students could also improve their critical thinking and look for pieces of information they could get in the reading stage. When making a mind map, students will work cooperatively with the other members of the group and can increase their teamwork skills by collaborating (Widyaningsih, 2018). As part of the cooperative learning condition, students are required to interact verbally with one another on learning tasks (Johnson \& Johnson, 2009), exchange opinions, explain things, teach others and present their understanding (Johnson, 2009). After discussing and making a mind map, the students will present their mind maps in front of the class. This stage is called the sharing stage. Students will be able to interact with other groups, and the other groups can ask the presenting group questions. Therefore, the stages in the RMS learning model will help students to sharpen their HOTS. Also, the researcher can advise educators to use other alternative learning models in teaching and learning activities, such as RMS. The results of this research can also be done further by changing to other concept or a different topic, and their impact on mastery of concepts and learning outcomes. 


\section{Conclusion}

The study result confirmed that both the RMS learning model and the concept mapping model can increase students' HOTS. The effectiveness of the model RMS of 0.60 indicates that the model has a fairly high impact on HOTS learners. Therefore, the RMS learning model would be more suitable to apply to increase students HOTS. The RMS learning model allows students to be creative and freer in making mind maps.

\section{Acknowledgment}

The author would like to thank Ruwaidah S.P. as the biology teacher in SMA Negeri 1 Ambawang and the Dean of Faculty of Teachers Training and Education of Universitas Muhammadiyah Pontianak for their support and help.

\section{References}

Balitbang. (2011). The Result of TIMSS Survey: 2011. Trends International Mathematics and Science Study. US: TIMSS and PIRLS International Study Center.

Cohen J. (1988). Statistical power analysis for the behavioral sciences. Lawrence Erlbaum, $2^{\text {nd }}$ ed.

Dewi N. (2016). Analisis Kemampauan Berpikir Kompleks Siswa Melalui Pembelajaran Berbasis Masalah Berbantuan Mind Mapping. In Bahasa. Edusains, 10.

Diani R. (2018). The Effectiveness of the RMS Model (Reading, Mind Mapping, and Sharing) on Concept Mapping Skills of Students. Indonesian Journal of Science and Mathematics Education, 4148.

Eppler M. (2006). A Comparison Between Concept Maps, Mind Maps, Conceptual Diagrams, and Visual Metaphors as Complementary Tools for Knowledge Construction and Sharing. Palgrave Journals. 202-210.

Fayakun M and Purnomo J. (2015). The Effectiveness of Physics Learning Using Contextual Model (CTL) with Predict, Observe, Explain Methods for Higher Order Thinking Skills. Jurnal Pendidikan Fisika Indonesia. 26-37.

Hidayat W. (2012). Improving Mathematical and Critical Thinking Abilities of High School Students through Think Talk Write Cooperative Learning. Seminar Nasional Penelitian dan Penerapan MIP (pp. 1-10). Yogyakarta: Universitas Negeri Yogyakarta.

Jalal F. (2009). Teacher Certification in Indonesia: A Strategy for Teacher Quality Improvement. Jakarta: Jurnal Departemen Pendidikan Nasional RI.

Johnson DW. (2009). Reaching out: Interpersonal effectiveness and self-actualization. Boston: Allyn \& Bacon.

Johnson DW and Johnson RT. (2009). An Educational Psychology Success Story: Social Interdependence Theory and Cooperative Learning. Educational Researcher, 365-279.

Kemristekdikti. (2018). Pengembangan IPTEK dan Pendidikan Tinggi di Era Revolusi Industri 4.0. Jakarta: Kemristekdikti.

Lewy Z and Aisyah N. (2009). Development of Questions to Measure Higher Order Thinking Skills on Rows and Arithmetic Sequences in Class IX Acceleration of Xaverius Maria Palembang Middle School. Jurnal Pendidikan Matematika, 14-28.

Muhlisin A. (2016). Improving Critical Thinking Skills of College Students Through RMS Model for Learning Basic Concepts in Science. Asia-Pacific Forum on Science Learning and Teaching, 1-24.

OECD. (2014). PISA 2012 Result: What Student Know and Can Do volume I. Canada: OECD. 
Prasetyani E. (2016). Higher Order Thinking Skills of XI Students in Problem-Based Trigonometry Learning at SMA Negeri 18 Palembang. Jurnal Gantang Pendidikan Matematika FKIP - UMRAH, 34-44.

Ramadhan F. (2016). The Potential of STAD Remap (Reading Concept Mapping Students Achievement Division) to Improve Students' Critical Thinking Skills. Seminar Nasional Biologi, Sains, Lingkungan dan Pembelajarannya (pp. 203-208). Surakarta: Universitas Sebelas Maret.

Raudenbush SW. (1992). Teaching for Higher-Order Thinking in Secondary Schools: Effects of Curriculum, Teacher, Preparation, and School Organization. Washington: Office of Educational Research and Improvement (ED).

Saregar A. (2016). Effectiveness of CUPS Learning Model: Impact on High Order Thinking Skills of Madrasah Aliyah Mathla'ul Anwar Gisting Lampung Students. Jurnal Ilmiah Pendidikan Fisika Al-BiRuNi, 233-243.

Supriatna A. (2018). Lesson Study Activities as Teachers' Efforts to Find Learning that Fulfills the Needs of Children Living in Their Times (Industrial Revolution 4.0 Era). Seminar Nasional Edusaintek. Semarang: UNIMUS.

Widyaningsih SW. (2018). Influence of RMS Model (Reading, Mind Mapping, and Sharing) on Student Learning Outcomes in School Laboratory Course. International Conference on Mathematics and Science Education (pp. 1-6). Bandung: Universitas Pendidikan Indonesia. 